\title{
HUBUNGAN SELF CONTROL TERHADAP PERILAKU KONSUMTIF BELANJA ONLINE PADA MAHASISWA
}

\author{
Nita Nilam Sari ${ }^{1}$, Nur Irmayanti ${ }^{2}$ \\ 1,2 Fakultas Psikologi Universitas Wijaya Putra Surabaya \\ Nitanilam88@gmail.com
}

\begin{abstract}
Students are one of the young people who are still unstable, need recognition from the social environment, and experience instability. In this case, the ability to control themselves or restraint becomes weak, so they tend to act on emotions. One of the problematic behaviors is buying behavior. This study aims to determine the relationship between student self-control with online shopping consumption behavior. This study uses quantitative methods with research design using correlational quantitative. The population in this study were teenage students with a subject of 70 teenage students. The sampling technique used is purposive sampling. The data collection tool uses a self-control scale and consumptive behavior. Data analysis using product moment correlation coefficient. The results showed a correlation of 0.983 with a significance of 0.000 because of the significance (<0.05), then Ho was rejected, meaning Ha was accepted. This means that there is a significant relationship between self control and online shopping consumptive behavior in adolescent students.
\end{abstract}

Keywords: Self control, Consumptive Behavior

\begin{abstract}
ABSTRAK
Mahasiswa merupakan salah satu anak muda yang masih labil, membutuhkan pengakuan dari lingkungan sosial, dan mengalami ketidakstabilan. Dalam hal ini, kemampuan untuk mengendalikan diri atau menahan diri menjadi lemah, sehingga mereka cenderung bertindak berdasarkan emosi. Salah satu perilaku yang bermasalah adalah perilaku pembelian. Penelitian ini bertujuan untuk mengetahui hubungan antara pengendalian diri remaja mahasiswa dengan perilaku konsumsi belanja online. Penelitian ini menggunakan metode kuantitatif dengan desain penelitian menggunakan kuantitatif korelasional. Populasi dalam penelitian ini adalah mahasiswa Remaja dengan jumlah subjek 70 mahasiswa remaja. Teknik pengambilan sampel yang digunakan adalah purposive sampling. Alat pengumpulan data menggunakan skala self control dan perilaku konsumtif. Analisis data menggunakan product moment correlation coefisien. Hasil penelitian menunjukkan korelasi sebesar 0,983 dengan signifikansi 0,000 karena signifikansi $(<0,05)$, maka Ho ditolak, berarti Ha diterima. Artinya ada Hubungan Yang Signifikan Antara Self control Dengan Perilaku Konsumtif Belanja Online Pada Mahasiswa Remaja.
\end{abstract}

Kata Kunci: Self control, Perilaku Konsumtif

32 Jurnal Psikologi Wijaya Putra Vol.2 No.2 November 2021 


\section{Pendahuluan}

Mahasiswa merupakan salah satu bagian dari masa remaja akhir. Adolescence disebut adolescene dalam bahasa aslinya. Berasal dari bahasa Latin adolescene (kata benda, teenia, yang berarti remaja), yang berarti "tumbuh hingga dewasa. Kata adolescene yang digunakan saat ini memiliki arti yang lebih luas, termasuk kematangan psikologis dan emosi. , Sosial dan fisik (Hurlock, 2004). Menurut William (Yusuf, 2008), mahasiswi yang termasuk dalam tahap akhir masa remaja memiliki tugas perkembangan, yaitu memperkuat pengendalian diri. Pada usia tersebut, mereka membutuhkan pengakuan dari lingkungan sosial, masih mencari jati diri, dan masih dalam keadaan emosi yang labil. Situasi ini cenderung melemahkan pengendalian diri, sehingga setiap keputusan yang diambil, termasuk keputusan pembelian, diatur oleh emosi sesaat.

Hal itu terlihat dari hasil penelitian Harnum (2012), yang menyatakan bahwa terdapat hubungan negatif yang signifikan antara kontrol diri dengan kecenderungan perilaku konsumtif pada Mahasiswi di Universitas X, yang artinya semakin tinggi tingkat kontrol diri mahasiswi maka semakin rendah kecenderungan perilaku konsumtifnya dan sebaliknya semakin rendah kontrol diri maka semakin tinggi pula kecenderungan perilaku konsumtifnya.

Belanja adalah kegiatan membeli barang dan jasa untuk memenuhi kebutuhan hidup seharihari. Dalam hidupnya, manusia membutuhkan berbagai macam kebutuhan, seperti tempat tinggal, pakaian, dan lain-lain. Dengan berkembangnya zaman, aktivitas belanja seperti ini bukan lagi untuk memenuhi kebutuhan pokok, melainkan untuk memuaskan. Bagi seorang mahasiswa dalam kehidupan yang kompetitif, hal ini tidak dapat dipisahkan. Siswa bebas mengenakan pakaian pilihannya, selama berada dalam ruang lingkup peraturan yang berlaku, sehingga siswa menjadi kompetitif, berpenampilan menarik, dan menggunakan barang-barang populer pada saat itu agar terlihat menarik.

Seorang mahasiswa yang menjaga penampilannya dengan mengikuti trend tentu akan terlihat lebih menarik, oleh karena itu membutuhkan beberapa barang yang diperlukan, seperti baju, celana, sepatu, dan aksesoris lainnya, dan juga untuk memperoleh barang-barang tersebut dengan mudahnya mereka bisa langsung membelinya melalui belanja online. Melalui belanja online kita dapat membeli suatu produk, melihat, bahkan menawar, dengan menggunakan metode berbelanja online, mahasiswa bisa berbelanja melalui banyak media sosial, antara lain seperti instagram, facebook, twitter, whatsapp, tokopedia, bukalapak, olx, zalora, dan masih banyak lagi. Konsumen hanya melakukan beberapa tahap untuk memesan serta tinggal menunggu barang 
pesanannya datang, sehingga begitu mudahnya berbelanja barang yang kita inginkan dan menjadi sangat terbantu dengan metode belanja shop tersebut.

Konsep belanja merupakan suatu sikap untuk mendapatkan barang yang menjadi kebutuhan untuk sehari-hari dengan menukarkankan sejumlah uang sebagai pengganti barang tersebut. Akan tetapi, pada saat ini konsep belanja itu merupakan sebuah cerminan gaya hidup serta rekreasi dikalangan masyarakat. Berbagai macam produk ditawarkan kepada konsumen. Produk ini tidak hanya barang yang dapat memuaskan kebutuhan seseorang, tetapi produk ini juga dapat memuaskan kesenangan konsumen.

Aspek-aspek perilaku konsumtif menurut Lina dan Rosyid (dalam Wardhani, 2009) ialah 1) pembelian Impulsif (impulsive buying). Aspek ini menunjkkan bahwa seorang membeli sematamata karena didasari oleh hasrat tiba-tiba atau keinginan sesaat, dilakukan tanpa terlebih dahulu mempertimbangkannya, tidak memikirkan apa yang akan terjadi kemudian dan biasanya bersifat emosional, 2) pemborosan (wasteful buying) Perilaku konsumtif merupakan salah satu perilaku yang menghamburkan-hamburkan banyak dana tanpa disadari adanya kebutuhan yang jelas. dan 3) mencari kesenangan (non rational buying) Suatu perilaku dimana konsumen membeli sesuatu yang dilakukan untuk mencari kesenangan.

Menurut Heni (2013) setiap isesorang memiliki suatu mekanisme yang dapat membantu mengatur perilaku, khususnya mahasiswi remaja. individu harus mampu mengatasi budaya konsumtif yang semakin berkembang. Hal ini berarti bahwa mereka dituntut untuk mampu menekan agar hawa nafsu serta perilakunya tersebut dapat teratasi. Sehingga perilaku konsumtif yang sudah menjamur dikalangan mahasiswi sekarang dapat diminimalis.

Self control menurut Borba (2009) merupakan kemampuan tubuh dan pikiran untuk melakukan apa yang mestinya dilakukan. Dalam hal ini self control membuat individu mampu mengambil pilihan yang tepat ketika menghadapi godaan, walaupun pada saat itu muncul pikiran dan ide buruk dikepalanya.

Individu yang memiliki self control tinggi akan sangat memperhatikan cara-cara yang tepat untuk berperilaku dalam situasi yang bervariasi. seseorang akan mudah mengubah perilakunya sesuai dengan permintaan situasi sosialnya sehingga dapat mengatur kesan yang dibuat. Perilaku yang lebih responsif terhadap petunjuk situasional, lebih fleksibel, berusaha untuk memperlancar interaksi sosial, serta bersikap hangat dan terbuka.

Kontrol diri melibatkan tiga hal. (1) Kontrol Perilaku, merupakan kesiapan seorang merespon suatu stimulus yang secara langsung memperoleh keadaan tidak menyenangkan dan 
langsung mengantisipasinya. (2.) Kontrol Kognitif merupakan kemampuan seseorang dalam mengolah informasi yang tidak diinginkan, dengan menilai maupun menghubungkan suatu kejadian dengan mengurangi tekanan, dan (3). Kontrol Keputusan merupakan kemampuan seseorang untuk memilih hasil ataupun suatu tindakan berdasarkan pada suatu hal yang diyakini (Ghufron dan Risnawita, 2012).

Adanya kontrol diri menjadikan seseorang dapat memandu, mengarahkan serta mengatur perilakunya dengan kuat sehingga pada akhirnya menuju pada konsekuensi yang positif (Golfried dan Mebaum dalam Utami dan Sumaryono, 2008).

Adanya self control menjadikan individu dapat memandu, mengarahkan dan mengatur perilakunya dengan kuat pada akhirnya menuju pada konsekuensi yang positif (Golfried dan Mebaum dalam Utami dan Sumaryono, 2008). Berdasarkan uraian permasalahan tersebut, penelitian ini bertujuan untuk mengetahui Hubungan Antara Self control Dengan Perilaku Konsumtif Belanja Online Pada Mahasiswa Remaja.

\section{Metode Penelitian}

Penelitian dilaksanakan pada tanggal 13 April 2021 hingga 18 juni 2021. Subjek penelitian ini ialah Mahasiswa/i Remaja. Sampel dalam penelitian diambil dengan menggunakan teknik purposive sampling. Adapun jumlah subjek dalam penelitian ini sebanyak 70 orang mahasiswa/i dengan rentan usia dari 18 hingga 22 tahun.

Instrumen yang digunakan didalam penelitian ini berupa skala self control dan skala perilaku konsumtif. Uji validitas self control dan perilaku konsumtif dilakukan dengan expert judgment ditambah juga dengan teknik corected itemm-totall corelation. Untuk pengujian reliabilitas skala self control dan perilaku konsumtif menggunakan program computer SPSS, yakni menggunakan tektik koefisien reabilitas Alpha Cronbach.

Hasil dari uji validitaas dan reliabilitas dari 30 aitem self control terdapat 30 aitem valid dengan nilai cronbach's sebesar 0,802. Sedangkan dari uji validitas dan reliabilitas dari 30 aitem skala perilaku konsumtif terdapat 30 butir aitem valid dengan nilai Cronbach's 0,928.

\section{Hasil dan Pembahasan}

Hasil

\section{Uji Validitas}

Pengujian instrument validitas penelitian dilakukan dengan cara yang biasa disebut expert judgment instrument yang akan dilakukan validasi diperiksa dan dievaluasi terlebihdahulu. Hasil 
pengukuran variable self control yang diperolah dari penelitian ini 30 aitem terdapat 30 aitem yang dikatakan valid karena menunjukkan rentan 0,216 - 0,606 dengan tTabel sebesar 0,195. Hasil pengukuran variable perilaku konsumtif yang diperolah dari penelitian ini 30 aitem terdapat 30 aitem yang dikatakan valid karena menunjukkan rentan 0,306-0,792 dengan tTabel sebesar 0,195

\section{Uji Realibilitas}

Reliabilitas adalah suatu instrumen cukup dapat dipercaya untuk digunakan sebagai alat pengumpul data karena instrumen tersebut sudah baik (Arikunto, 2006). Instrumen yang baik tidak akan bersifat tendensius mengarahkan responden untuk memilih jawaban-jawaban tertentu. Reliabel artinya, dapat dipercaya, jadi dapat diandalkan. Perhitungan reliabiitas dimulai setelah dilakukan uji validitas, kemudian item yang valid dicari koefisiennya dengan teknik Cronbach Alpha.

\begin{tabular}{|ll|r|r|}
\hline \multicolumn{2}{c|}{ Correlations } & \\
\hline SELF_CONTROL & SELF_CONTROL & PERILAKU_KONSUMTIF \\
& Pearson Correlation & 1 & $-.983^{* *}$ \\
& Sig. (2-tailed) & & .000 \\
& $\mathrm{~N}$ & 70 & 70 \\
\hline PERILAKU_KONSUMTIF & Pearson Correlation & $-.983^{* *}$ & 1 \\
& Sig. (2-tailed) & .000 & \\
& $\mathrm{~N}$ & 70 & 70 \\
\hline
\end{tabular}

**. Correlation is significant at the 0.01 level (2-tailed).

Reliabilitas dinyatakan dengan koefisien reliabilitas yang angkanya berada dalam rentang 0 hingga 1,00 berarti semakin tinggi koefisien reliabilitas mendekati angka 1,00 berarti semakin tinggi reliabilitas.

Hasil uji reliabilitas dalam penelitian ini dibantu dengan bantuan Microsoft Excel 2010 dan SPSS 22.00 for windows, hasil koefisien reliabilitas pada variabel kontrol diri sebesar 0.802 Sedangkan pada variabel perilaku konsumtif sebesar 0.928. Angka tersebut mampu mengambarkan bahwa instrumen yang digunakan dalam penelitian ini adalah reliabel karena menunjukkan angka $>0.5$.

\section{Uji Hipotesis}

Berdasarkan tabel di atas, diperoleh hasil koefisien korelasi (rxy) antara self control dengan perilaku konsumtif sebesar $-0,983$ dengan signifikansi $p=0,000(p<0,05)$. Koefisien korelasi 
tersebut menunjukkan adanya hubungan negatif antara kedua variabel, yang berarti semakin tinggi self control maka semakin rendah perilaku konsumtif mahasiswa remaja. Begitupun sebaliknya, jika semakin rendah self control maka perilaku konsumtif mahasiswa remaja akan semakin tinggi. Hasil tersebut menunjukkan bahwa hipotesis penelitian yang menyatakan adanya hubungan negatif antara self control dengan perilaku konsumtif mahasiswa remaja dapat diterima.

Kemampuan remaja untuk mengontrol dirinya akan bertambah seiring dengan bertambahnya usia (Monahan, Steinberg, Cauffman, \& Mulvey, 2009). Hal ini diperkuat dengan penelitian sebelumnya, yang menyatakan bahwa tingkat self control pada remaja berpengaruh positif dengan tingkat pendidikan yang ditempuh. (Allen \& Glanzer, 2017). Hal ini sesuai dengan penyataan Baumeister, Vohs, dan Tice (2007) yang menyatakan bahwa lingkungan perkuliahan dapat mempengaruhi perkembangan self control pada mahasiswa remaja.

Penelitian Anggreini dan Marianti (2014) mengkonfirmasi hasil penelitian ini, dimana terdapat hubungan negatif yang signifikan antara pengendalian diri dengan perilaku konsumtif pada mahasiswa Universitas Esa Unggul yang artinya semakin tinggi derajat pengendalian diri maka semakin tinggi tingkat pengendalian diri. menurunkan perilaku konsumen, begitu pula sebaliknya.

\section{Pembahasan}

Berdasarkan data yang disajikan dapat disimpulkan bahwa, Analisis menunjukan adanya hubungan antara kontrol diri dengan perilaku konsumtif dilihat dari nilai korelasi sebesar $\mathrm{r}=$ 0,983. Nilai yang didapat menunjukan terdapat adanya hubungan negatif diantara variabel tersebut. Hasil (r) yang negatif pada korelasi tersebut menunjukan bahwa adanya hubungan terbalik antara kontrol diri dengan perilaku konsumtif belanja online pada mahasiswa remaja, yaitu semakin rendah kontrol diri maka akan semakin tinggi pula perilaku konsumtif seseorang dan juga sebaliknya.

Hal ini didukung penelitian dari Astuti (2013), bahwa perilaku konsumtif adalah kecenderungan seorang individu untuk membeli yang tidak dibutuhkan Penelitian Tifani (2014), juga menyatakan beberapa hal yang sama, yakni bahwa seseorang yang kontrol diri yang rendah akan memiliki perilaku konsumtif yang tinggi, dan demikian juga sebaliknya, dimana mahasiswa remaja memiliki tingkat self-control yang tinggi. Mahasiswa remaja yang memiliki tingkat selfcontrol yang tinggi mendorong mahasiswa untuk mengendalikan perilaku serta mempertimbangkan konsekuensi untuk melakukan perilaku tersebut. Untuk itu Adanya 
pertimbangan secara rasional sebelum melakukan suatu pembelian dapat menekan perilaku konsumtif seseorang.

Hal ini didukung penelitian dari Astuti (2013), bahwa perilaku konsumtif adalah kecenderungan seorang individu untuk membeli yang tidak dibutuhkan Penelitian Tifani (2014), juga menyatakan beberapa hal yang sama, yakni bahwa seseorang yang kontrol diri yang rendah akan memiliki perilaku konsumtif yang tinggi, dan demikian juga sebaliknya, dimana mahasiswa remaja memiliki tingkat self-control yang tinggi. Mahasiswa remaja yang memiliki tingkat selfcontrol yang tinggi mendorong mahasiswa untuk mengendalikan perilaku serta mempertimbangkan konsekuensi untuk melakukan perilaku tersebut. untuk memperoleh pertimbangan secara rasional sebelum melakukan pembelian dapat menekan perilaku konsumtif individu.

Hal ini sesuai dengan hasil penelitian Anggreini dan Maryanti (2014) yang menjelaskan siswa dengan perilaku konsumsi rendah, karena sebagai siswa dapat menentukan produk sesuai dengan kebutuhannya sendiri, mereka tetap membeli produk, tetapi sesuai dengan kebutuhan. dari kuliah.

Hal ini juga didukung oleh penelitian Fatimah (2013). Siswa dengan pengendalian diri yang kuat cenderung mengarahkan perilakunya ke arah pemikiran yang positif dan baik dengan berfokus pada hal-hal yang dapat membawa manfaat dan pengambilan keputusan yang cermat.

Utami dan Sumaryono (2008) mengungkapkan bahwa self-control adalah sistem pengendalian diri dalam individu yang dapat menekan hingga menghindari perilaku konsumtif. Hal ini sejalan dengan penelitian sebelumnya Robert dan Manolis (dalam Afandi \& Hartati, 2017) bahwa kontrol diri memiliki hubungan negatif terhadap pembelian impulsif.

Mahasiswa remaja lebih banyak yang memiliki self control tinggi dibandingkan self control rendah. Ini dikarena remaja akhir telah mulai dapat memahami, mengarahkan, mengembangkan dan memelihara identitas diri. Remaja akhir juga telah mulai stabil serta mantap, mengenal arah hidupnya, serta sadar pada tujuan yang dicapainya dan pendiriannya sudah mulai jelas sehingga self control pada mahasiswa cenderung tinggi. Teori self control tentang faktor internal dari self control yang menyatakan bahwa semakin bertambahnya usia seseorang maka semakin baik pula kontrol dirinya, individu yang matang secara psikologis juga akan mampu mengontrol perilakunya karena sudah mampu mempertimbangkan mana hal yang baik serta yang tidak baik untuk dirinya.

Dari penelitian ini jelas bahwa ketika seseorang memiliki tingkat self control yang tinggi, maka perilaku konsumtif belanja online rendah. Hal ini sesuai dengan pendapat Munandar yang 
mengungkapkan bahwa self control merupakan salah satu sifat keperibadian yang mempengaruhi perilaku individu dalam membeli barang mapun jasa. Begitu pula dengan pendapat Mar'at bahwa individu yang memiliki self control tinggi yang mampu mengubah kejadian serta menjadi agen utama dalam mengarahan dan mengatur perilaku yang membawa kepada konsekuensi yang positif.

\section{Kesimpulan}

Berdasarkan hasil penelitian dapat disimpulkan bahwa terdapat hubungan antara selfcontrol dengan perilaku konsumtif belanja online dengan nilai sig. $=0,000$ dengan demikian nilai sig. $<0,05$. Koefisien korelasi $-0,983$ menunjukkan bahwa hubungannya tinggi. Tanda negatif artinya semakin tinggi self control maka semakin rendah tingkat perilaku konsumtifnya, begitu pula sebaliknya.

\section{Daftar Pustaka}

Afandi, A. R., \& Hartati, S. (2017). Pembelian impulsif pada remaja akhir ditinjau dari kontrol diri. Gadjah Mada Journal of Psychology, 3(3), 123-130.

Allen, C. C. \& Glanzer, P. L. (2017). How college student understand theri self-control development: A qualitative analysis. Journal of College and Character, 18(3), 187- 201.

Anggreini, R., \& Mariyanti, S (2014). Hubungan antara kontrol diri dan perilaku konsumtif. Psikologi, 12, 40

Arikunto, Suharsami. 2006. Prosedur Penelitian Suatu Penelitian Praktik. Jakarta : Reneka Cipta.

Astuti, D.E. (2013). Perilaku Konsumtif dalam Membeli Barang pada Ibu Rumah Tangga di Kota Samarinda. Jurnal Psikologi, 1(2). Diakses dari ejournal .psikologi.fsipunmul.ac.id

Baumeister, R., Vohs, K. D., \& Tice, D. M. (2007). The strength model of self-control. Current Directions in Psychological Science, 16(6), 351-355.

Bhuwaneswary, A. (2016). Perilaku belanja online dan kontrol diri mahasiswa Belitung di $\begin{array}{llll}\text { Yogyakarta } & \text { (Yogyakarta). } & \text { Retrieved }\end{array}$ http://journal.student.uny.ac.id/ojs/index.php/fipbk/search/authors/view?firstName=Ang graini\&middleName\&lastName=Bhuwaneswary\&affiliation=\&country=

Borba, M. (2009). Membangun Kecerdasan Moral. Jakarta: PT. Gramedia Pustaka Utama.

Chita, R. C. M., David, L., \& Pali, C. (2015). Hubungan antara self-control dengan perilaku konsumtif online shopping produk fashion pada mahasiswa fakultas kedokteran universitas sam ratulangi angkatan 2011. Jurnal E-Biomedik,3(1). https://doi.org/10.35790/ebm.3.1.201 $\underline{5.7124}$ 
Erlyanawati, E. (2016). Hubungan antara kontrol diri degan perilaku konsumtif online shopping pada mahasiswa Fakultas Psikologi Universitas Muhammadiyah Surakarta (Muhammadiyah Surakarta). Retrieved from http://eprints.ums.ac.id/48571/38/PU BLIKASI ILMIAH BARU.pdf

Ghufron, M. N., dan Risnawati. R. (2011). Teori-teori Psikologi. Yogyakarta: ArRuzz Media

Harnum, D. (2012). Hubungan antara Teknik Kontrol Diri dengan Kecenderungan Perilaku Konsumtif Mahasiswi di Ma'had Sunan Ampel Al-Aly Universitas Islam Negeri (UIN) Maulana Malik Ibrahim Malang. Skripsi. Diterbitkan : Fakultas Psikolog Universitas Islam Negeri Malang

Heni AS. Hubungan antara Kontrol Diri dan Syukur dengan Perilaku Konsumtif pada Remaja SMA IT Abu Bakar Yogyakarta. 2012;1-15.

Heni, S. A. (2013). Hubungan SMA IT antara Kontrol Diri dan Syukur dengan Perilaku Konsumtif Pada Remaja Abu Bakar Yogyakarta. Jurnal Psikologi.

Heryani, I. \& Herwanto, J. (2015). Hubungan Konformitas dan Kontrol Diri Dengan Perilaku Konsumtif Terhadap Produk Kosmetik pada Mahasiswi. Jurnal Psikologi. 2(1). Diakses dari http://ejournal.uinsuskasa.ac.id/fpasdpsikologig/view/1555

Hurlock, E. B. (2004). Psikologi Perkembangan Suatu Pendekatan Sepanjang Rentang Kehidupan. Jakarta : Erlangga

Monahan, K., Steinberg, L., Cauffman, E., \& Mulvey, E. (2009). Trajectories of antisocial behavior and psychosocial maturity from adolescence to young adulthood. Developmental Psychology, 45(6), 1654-1668. Doi: 10.1037/a0015862.

Shohibullana HI. Kontrol Diri dan Perilaku Konsumtif pada Siswa SMA(Ditinjau dari Lokasi Sekolah). Jurnal Online Psikologi. Malang. 2014;02(01):46- 619.

Tambunan, R. (2001). Remaja dan Perilaku Konsumtif. Artikel. http://www. scribd. com/doc/12007850/Remaja-Dan Perilaku-Konsumtif, diakses tanggal 26 April 2014.

Tifani. (2014). Hubungan Antara Kontrol Diri Dengan Perilaku Konsumtif Membeli Pakaian Diskon Pada Mahasiswi Fakultas Hukum Universitas Sriwijaya Palembang. Jurnal Psikologi. 8(2). Diakses dari http://jurnals.binadarma.ac.id/indexs/jurnalpsyc he/392/165

Tripambudi, B., \& Indrawati, E. S. (2018). Hubungan Antara Kontrol Diri Dengan Perilaku Konsumtif Pembelian Gadget Pada Mahasiswa Teknik Industri Universitas Diponegoro. Empati, 7(2), 189-195. 
Utami, F. A., dan Sumaryono. (2008). Pembelian Impulsif Ditinjau Dari Kontrol Diri dan Jenis Kelamin Pada Remaja. Jurnal Psikologi Proyeksi. 3 :46-57.

Wardhani, M. D. (2009). Hubungan antara Konformitas dan Harga Diri dengan Perilaku Konsumtif Pada Remaja Putri. Skripsi. Surakarta: Fakultas Kedokteran Progam Studi Psikologi Universitas Sebelas Maret.

Wardhani, M. D. (2009). Hubungan antara Konformitas dan Harga Diri dengan Perilaku Konsumtif Pada Remaja Putri. Skripsi. Surakarta: Fakultas Kedokteran Progam Studi Psikologi Universitas Sebelas Maret.

Yusuf, S. 2008. Psikologi Perkembangan Anak dan Remaja. Bandung : PT Remaja Rosdakary 